\section{Posokhov I., Khodyrieva 0.}

\title{
RESEARCH OF RISK MANAGEMENT TRENDS IN UKRAINE
}

Розглянуто сучасний стан управління ризиками в Украйні. Виділено основні фактори господарсъкого ризику для українських підприємств. Виокремлено потреби української системи управління ризиками, а також специфічні особливості вітчизняного ризик-менеджменту, обгрунтовано необхідність його подальшого дослідження та розвитку. Запропоновано процедуру вибору заходів з управління ризиками на промислових підприємствах.

ключові слова: управління ризиками, фактори ризику, методи ризик-менеджменту.

\section{Introduction}

The current trends in the world economy determine the constant need to search for new methods and measures to minimize and control economic risk and its negative impact on entrepreneurial activity. Ukrainian enterprises operate in conditions of unstable economic and political situation in the country, inadequate purchasing power of the population, which leads to high uncertainty of forecasts regarding possible demand, production costs, profitability (rate of return) and results of economic activity. In addition, due to the ongoing process of European integration, modern companies have to bring their activities in line with international standards in order to occupy the segments of the world market and successfully compete in them. Understanding and applying risk management techniques enables to make strategically correct decisions, to occupy a profitable market position in order to increase the level of profitability and sustainable development of the enterprise. That is why risk management must take a key position in the management structure of a modern enterprise.

\section{The object of research and its technological audit}

The object of research is the state of risk management in Ukraine and its inherent characteristics, with the aim of increasing the effectiveness of risk management in enterprises. To highlight the problems of Ukrainian risk management, views of Ukrainian scientists in their works are analyzed. Also considerable attention is paid to foreign experience in risk management, in particular FERMA (Federation of European Risk Management Association) risk management standards, which explains risk management as the central part of the organization's strategic management.

\section{The aim and objectives of research}

The aim of research is analysis of the current state of risk management in the state and recommendations for selection of risk management measures at industrial enterprises.

To achieve this aim, the following tasks are accomplished:

1. To investigate the state of risk management in Ukrainian enterprises.
2. To identify the specific features of Ukrainian risk management.

3. To develop a procedure for selection of risk management measures at industrial enterprises.

\section{Research of existing solutions of the problem}

Research of the economic risks and conditions under which they occur is engaged in a number of scholars and practitioners. The theoretical basis for article is a number of works by foreign and domestic scientists in which are considered:

- theoretical and methodological and applied provisions substantiation of economic decisions [1];

- the theoretical basis for identifying risk situations, assessing the level of their impact [2];

- the essence of risk management, its place in the activity of enterprises and practical aspects of risk analysis in the enterprise as a whole and in its various divisions [3];

- the features of forecasting and justification of the optimal choice of alternative solutions are revealed [4]; - the authors give recommendations on increasing the level of effective risk management in the enterprise [5]; - the topical issues of the essence of economic diagnostics risks of enterprise functioning, risk assessment of the management activity of the enterprise and its control are revealed [6, 7];

- the concept of integrated risk management is given [8]; - the prospects for development of strategic management of economic organizations in contemporary socioeconomic conditions are outlined [9];

- it is paid attention to international standardization in the domain of risk management [10].

Despite the large number of scientific papers, selected issues of risk management is not covered in full. In particular, contemporary Ukrainian specifics of risk management is insufficiently investigated, the system and risk management practices in Ukrainian enterprises are few considered.

\section{Methods of research}

To solve the problems, the following methods are used: analysis and synthesis, logical generalization, analogies, 
comparative comparisons, monographic and grapho-analytical methods.

\section{Research results}

An obligatory condition for effective entrepreneurial activity in a market economy is the availability of economic freedom in the subjects of the market, that is, a certain set of rights that guarantee autonomous and independent decision-making. But economic freedom at the same time is a source of uncertainty and risk, since the freedom of one subject has the freedom of all others. In the Economic Code of Ukraine, art. 42 it is stated that entrepreneurship is an independent, initiative, systematic, at its own risk, economic activity, carried out by business entities (entrepreneurs) with the goal of achieving economic and social results and making a profit [11]. Thus, the link between the implementation of entrepreneurial activity and the risk is fixed at the legislative level. Therefore, «the study of risk ... and measures to reduce its negative impact is an indispensable tool that determines the effectiveness of entrepreneurial activities» [12].

Risk management is defined as «the process of systematic identification of critical risks, assessment of their impact, development and implementation of an integrated risk management solution that integrates strategy, personnel, processes and technologies» [13]. It seems advisable to consider the features and current state of risk management at macro and micro levels in Ukraine.

The urgent problem of the modern economy of Ukraine is the problem of risk increasing. This is confirmed by economic and political instability in the country, according to official statistical data on the growth of loss-making enterprises, depreciation of the material and technical base and other data. However, standardized risk management techniques are not widely used and are not always applied, and those that are used and have significant drawbacks. In connection with the foregoing, there is a need to intensify the development and improvement of the methodological framework for risk management, its adaptation to the current state of the Ukrainian economy, and the introduction of the main components of modern global standards in the field of risk management. «Analysis requires the joining efforts of specialists of all levels, the deputy corps, specialists in manufacturing enterprises, businessmen and workers of the banking system and non-bank financial institutions, scientists and specialists of all relevant areas» [14].

There are the views that the central problem of the modern business entity is the development of a survival strategy. It is of particular importance for public and private enterprises and adheres to the following objectives:

- adaptation to market conditions;

- avoiding of inefficient methods of management that are exhausted themselves;

- ensuring the stability of economic activity;

- preservation of the resource potential, especially the team of highly qualified specialists and managers [15]. However, the basic mechanisms for applying this strategy are not clearly defined. In addition, it is known that a too moderate management strategy for a long time can lead to loss of the enterprise, due to changes in external and internal factors. At the same time, let's note that in 2016, according to State Statistics State of Ukraine, almost $33 \%$ of enterprises suffered losses totaling 188 billion UAH [16].
In the current economic situation it is proposed to hold the opinion that the system of market relations objectively determines the existence of risk in all spheres of economic activity. The market environment brings elements of uncertainty and the risk situations to the activities of enterprises. They arise in specific circumstances. Risk situations form the conditions for the existence and implementation of the economic risk faced by virtually all industrial enterprises in the course of their activities. Enterprises for survival, instead of avoiding risk, need to be able to correctly assess its degree and manage it in order to control its size. That is why Ukrainian enterprises need to timely take into account risk factors when making managerial decisions; the qualified organization of the risk management process, which is aimed at ensuring the adaptation of the enterprise's activities to the conditions of the external and internal environment that is constantly changing [4].

It should also be noted that in Ukraine there are specific reasons for the occurrence of economic risk. The most important among them is the unstable political situation, the advantage of political interests over economic interests, high level of inflation, unsustainable constantly changing tax legislation, the contradictoriness of the law and so on. As it can be seen, the majority of factors that determine the level of riskiness of the economic activity of an enterprise in Ukraine are external factors. Scientists share external risk factors in Ukraine on the factors of direct and indirect action. Factors of direct action include instability of the legislation and unforeseen actions of state bodies, unsustainable economic policy, drastic changes in market conditions and unpredictable actions of competitors, corruption, racketeering and so on. Factors of indirect impact are instability of political and social conditions, unpredictable changes in the international environment, economic environment in the region, etc. [2].

Some scientists pay attention to the fact that the concept of protection of the Ukrainian market, domestic entrepreneurship from low-quality imported products has not yet been introduced in the country. They also point to the need to create information systems or databases in which it is possible to obtain exhaustive information about a partner or counterparty, thus avoiding risks associated with their unreliability [1].

The development of risk management is affected by the shortcomings of the Ukrainian tax system, namely, constant changes and amendments to the laws and the tax code that deprive entrepreneurs of confidence in their performance for increasing uncertainty, and increase the level of tax and economic risks. To this it can add that all tax risks affect small business entities, and medium and large business entities are forced to evade taxes. The urgency and the need for rapid introduction of risk management methods in enterprises in modern conditions can be confirmed by the following arguments:

- economic and legal independence of domestic enterprises, which has not only the ability to determine its financial and production policies, but also the lack of state support in the event of an accident, strike, financial or other difficulties;

- dependence of incomes of local budgets on the effectiveness of enterprises in their territory;

- increase in the number and severity of the consequences of major industrial accidents, which is explained 
by the excessive level of depreciation of fixed production assets; ineffective practice of productive forces location; completely not formed economic mechanisms of ensuring security and regulatory and legal framework in the field of protecting the population and territories from industrial accidents and disasters;

- increasing role and importance of financial markets for the country's economy;

- experience of inadequate management of enterprises in times of crisis;

- globalization of the economy that increases existing risks and causes the emergence of new risks [3].

Many scientists in their studies of entrepreneurial risks write that in Ukraine there is growing interest in the problems of risk management on the part of scientists, managers and practitioners. In the new concepts of management, the risk starts to be associated not only with losses, but also with the possibility of obtaining additional profit in the presence of an effective business risk management strategy. At the same time, they note that modern methods of risk management are only beginning to be used by domestic companies, mainly in the banking sector and large industrial corporations, where certain main types of risk have been investigated to some extent. In general, the existing theoretical developments have not yet found wide application and implementation in practice in the field of domestic business, especially for small businesses, where in fact the only method of minimizing risks is insurance. One of the reasons for such situation, in their opinion, is that despite a huge number of scientific publications devoted to the study of problems of risk management, the methodological foundations of the formation of a system of risks for specific subjects of entrepreneurial activity have not yet been developed [17-21].

It should be noted that the risks, in which the Ukrainian enterprises operate, are very diverse, so in practice, the efforts of managers are mainly aimed at minimization of the impact of production risks on the enterprise activities. There are forecasts that in the near future there will be a change of priorities and the main efforts will be directed to production in the financial sphere [15].

Some specialists in Ukrainian enterprises dealing with risk management (system administrators (information risks), financiers (financial risks)). However, their activities in this case are not coordinated in comparison with foreign enterprises and foreign management experience, in which risk management is central not only in private companies, but also in non-profit organizations and government agencies. In particular, there are organizations in the United States that unite risk managers in public administration, public sector, medicine, higher education [5].

The orientation of Ukraine to a market-type economy contributes to the emergence of various types of uncertainty for all subjects of its economic activities.

But, according to the survey results, the general managers of Ukrainian enterprises in risk management certainly rely on their own intuition, certain authority and on existing experience, and only a small part of managers can assess risk using mathematical methods [6].

Analyzing the foregoing, it can highlight the specific features of risk management in Ukraine:

- lack of a risk management infrastructure and standards for its implementation;
- significant differences in the Ukrainian and foreign risk profiles for companies, most of the risk factors in Ukraine - external factors;

- inefficient state risk management advantage of political interests over economic;

- high level of political risk;

- numerous schemes of the shadow economy give rise to uncertainty conditions a high level of economic risk.

The integration of Ukraine into the world market and development of all types of entrepreneurial activity in the country intensifies the need to study and implement world experience with the needs of risk management in Ukraine. Most widely foreign companies use an integrated approach to implementation of risk management, the principles of which are considered in the FERMA risk management standards developed by leading UK organizations [22]. The traditional obsolete risk management system «from below to up» is used in Ukraine. When choosing a risk management model in Ukrainian companies, it is necessary to take into account the state of the organization itself, its life cycle, strategic goals. At some stages, a complex system is inefficient and a traditional concept needs to be used.

In order to choose an effective risk management process, let's distinguish the following groups among existing enterprises:

- newly established enterprises - enterprises that begin their activities in the Ukrainian market;

- enterprises in the stage of formation - functioning for some time, are looking for opportunities for further development;

- enterprises that focus on active growth - which extend their activities to new market segments or assimilate the production of new products;

- enterprises that have achieved their strategic goals - corporations, which require continuous adaptation to market changes.

The procedure for selection of risk management measures is shown in Fig. 1. The application of this procedure allows to choose the risk management measures in accordance with the strategic objectives of the organization.

The application of this procedure allows to choose the risk management measures in accordance with the strategic goals of the organization. So, for new enterprises and those that are in the stage of development, let's consider it inappropriate to apply an integrated approach to risk management for the high costs of its implementation and the shortage of staff in the corresponding specialization. For them it is enough to control the most threatening risks by the method of internal accounting data analysis. For enterprises in the phase of active growth and for those that have already achieved strategic goals, it is proposed to use a risk management system based on the integrated approach and FERMA risk management standards. Such system protects the organization and promotes its capitalization by:

- a systematic approach that allows to plan and implement the organization's long-term activities;

- improvement of decision-making and strategic planning;

- the most effective use of capital and resources of the organization;

- optimization of business processes;

- staff development. 


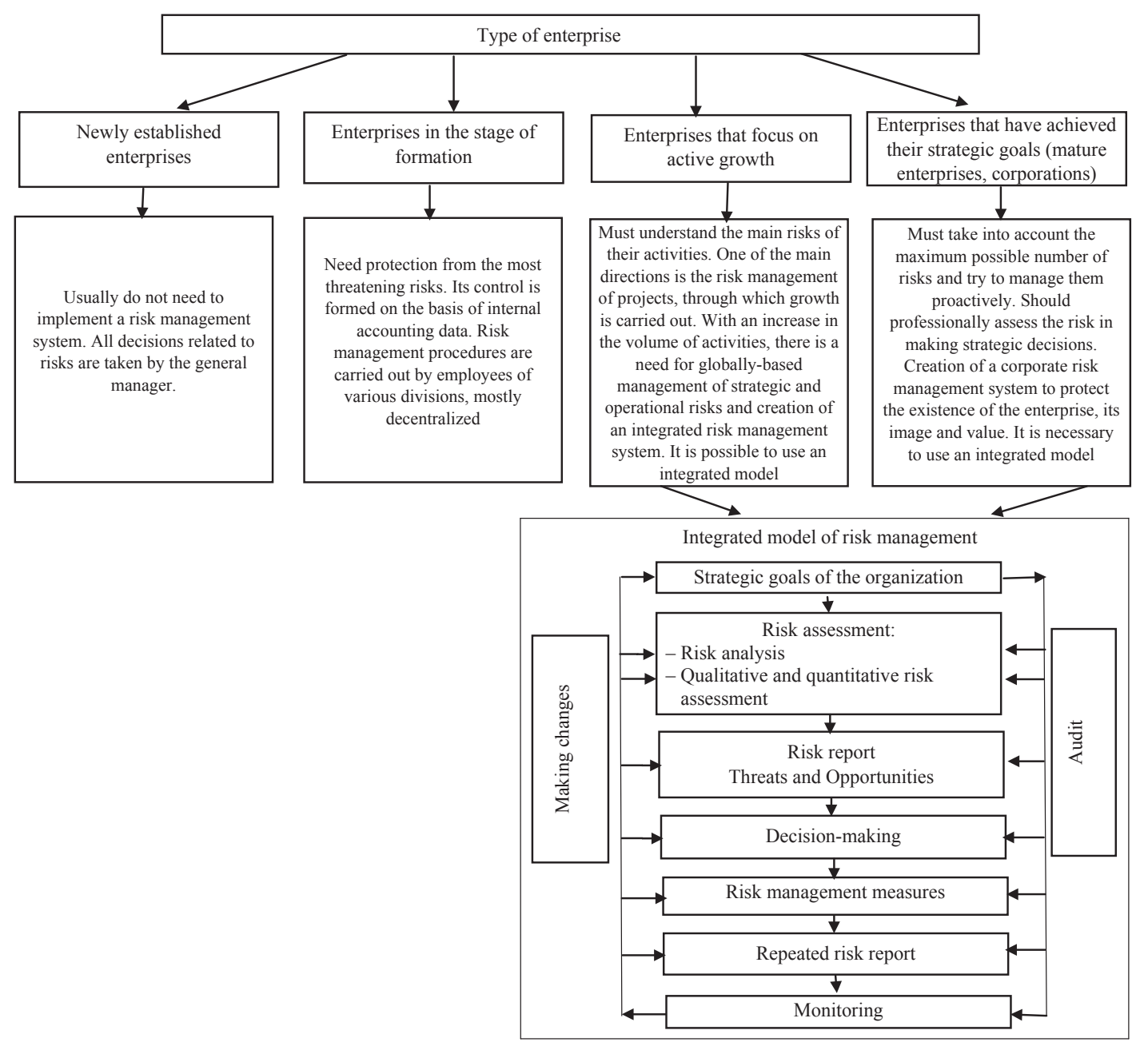

Fig. 1. Procedure for selection of risk management measures. Suggested by the authors

\section{SWOT analysis of research results}

Strength. The strength of research is that the proposals made on the application of risk management measures allow to mitigate the negative impact of environmental factors on the activities of the enterprise. This, in turn, will positively affect the relevant indicators of the economic activity of the enterprise.

Weaknesses The weak side of research is the high level of material costs for organization of the risk management process in the enterprise, as well as the shortage of personnel of the relevant qualification.

Opportunities. The opportunities for further research and proposals are borrowing foreign experience in applying risk management and its adaptation to the needs of Ukrainian enterprises.

Threats. The threats to the results of conducted research is a high level of uncertainty of the external environment, entailing a change in existing risks and the level of their influence in future periods.

\section{Conclusions}

1. As research result, it is determined that risk management in Ukraine is not common and is only beginning to be applied by domestic companies, mainly in the banking sector and large industrial corporations, where the main profile types of risk have been investigated to some extent.
Most of the existing theoretical developments have not yet been widely disseminated and implemented in practice.

2. This research identifies specific features of Ukrainian risk management, such as lack of its own risk management infrastructure and standards for its implementation, significant differences in Ukrainian and foreign risk profiles for enterprises, ineffective state risk management, high level of political risk, etc.

3. The authors proved the need to improve the traditional risk management system for Ukraine and suggested a procedure for risk management measures that takes into account the world's experience in risk management, as well as features of the existing approach in Ukraine. The procedure emphasizes the following aspects:

- use and combination of an integrated approach with traditional domestic risk management practices;

- taking into account the strategic goals of the enterprise;

- taking into account the life cycle of the enterprise.

Directions of further scientific research are the prerequisites for further development of tools and models of risk management for domestic industrial enterprises.

\section{References}

1. Baldzhy, M. D. Obgruntuvannia hospodarskykh rishen ta otsinka ryzykiv [Text] / M. D. Baldzhy, V. A. Karpov, A. I. Kovalov et al.; ed. by M. D. Baldzhy. - Odesa: ONEU, 2013. - 670 p. 
2. Barantseva, S. M. Ryzykolohiia [Text] / S. M. Barantseva, T. B. Khlevytska. - Donetsk: DonNUET, 2011. - 224 p.

3. Starostina, A. O. Ryzyk-menedzhment: teoriia ta praktyka [Text]: Handbook / A. O. Starostina, V. A. Kravchenko. - Kyiv: IVTs «Vydavnytstvo «Politekhnika»», 2009. - 200 p.

4. Donets, L. I. Ekonomichni ryzyky ta metody yikh vymiriuvannia [Text]: Handbook / L. I. Donets. - Kyiv: Tsentr navchalnoi literatury, 2006. - $312 \mathrm{p}$

5. Kasatkin, B. P. Metodologicheskie aspekty upravleniia riskami promyshlennogo predpriiatiia [Text]: Monograph / B. P. Kasatkin. - St. Petersburg: FGBOUVO «SPbGUPTD», 2016. - 88 p.

6. Sakhartseva, I. I. Ryzyky ekonomichnoi diahnostyky pidpryiemstva [Text]: Handbook / I. I. Sakhartseva, O. V. Shliaha. Kyiv: Kondor, 2007. - 285 p.

7. Krichevskii, M. L. Finansovye riski [Text]: Handbook M. L. Krichevskii. - Moscow: KNORUS, 2012. - 248 p.

8. Kudriavtsev, A. A. Integrirovannyi risk-menedzhment [Text]: Handbook / A. A. Kudriavtsev. - Moscow: Ekonomika, 2010. - 655 p.

9. Fomichev, A. N. Strategicheskii menedzhment [Text]: Handbook / A. N. Fomichev. - Moscow: Dashkov i Ko, 2010. - 468 p.

10. Avdiiskii, V. I. Riski hoziaistvuiushchih subiektov. Teoreticheskie osnovy, metodologii analiza, prognozirovaniia i upravleniia [Text] / V. I. Avdiiskii, V. M. Bezdenezhnyh. - Moscow: Alfa-M: INFRA-M, 2013. - $368 \mathrm{p}$

11. Economic Code of Ukraine [Text]. - Kyiv: European University, 2014. - 256 p.

12. Shapkin, A. S. Ekonomicheskie i finansovye riski. Otsenka, upravlenie, portfel' investitsii [Text]: Monograph / A. S. Shapkin. - Moscow: Izdatelsko-torgovaia korporatsiia «Dashkov i Ko», 2010. - 544 p.

13. Badalova, A. G. Upravlenie riskami innovatsionnoi deiatel'nosti promyshlennyh predpriiatii [Text] / A. G. Badalova, A. A. Nazarova // Innovatsii. - 2016. - № 8. - P. 51-56.

14. Pikus, R. V. Upravlinnia finansovymy ryzykamy [Text]: Handbook / R. V. Pikus. - Kyiv: Znannia, 2010. - 598 p.

15. Vitlinskyi, V. V. Ryzykolohiia v ekonomitsi ta pidpryiemnytstvi [Text]: Monograph / V. V. Vitlinskyi, H. I. Velykoivanenko. - Kyiv: KNEU, 2004. - 480 p.

16. Finansovi rezultaty velykykh ta serednikh pidpryiemstv do opodatkuvannia za vydamy ekonomichnoi diialnosti za sichen-veresen 2016 roku [Electronic resource] // State Statistics Service of Ukraine. - Available at: \www/URL: http:// www.ukrstat.gov.ua/operativ/operativ2016/fin/fin_rez/fr_ed/ fr_ed_u/fr_ed 0316 u.htm
17. Posokhov, I. M. Teoretychni ta praktychni aspekty upravlinnia ryzykamy korporatsii [Text]: Monograph / I. M. Posokhov. Kharkiv: PVPP «SLOVO», 2014. - 499 p.

18. Posokhov, I. M. Analysis of risk category and scientific approaches to determination of risk [Text] / I. M. Posokhov / Visnyk natsionalnoho technichnoho universytetu «KhPI». 2012. - № 5. - P. 101-108.

19. Posokhov, I. M. Operatsiini ryzyky: upravlinnia ta osnovni napriamy znyzhennia [Text] / I. M. Posokhov // Visnyk ekonomiky transportu i promyslovosti. - 2012. - № 37. - P. 229-233.

20. Posokhov, I. M. Suchasni tendentsii mizhnarodnykh ekonomichnykh vidnosyn. Ekonomichna intehratsiia Ukrainy u svitove hospodarstvo [Text]: Monograph / I. M. Posokhov. - Kharkiv: NTU «KhPI», 2016. - 450 p.

21. Saraieva, I. M. Systemne modeliuvannia protsesu identyfikatsii pidpryiemnytskykh ryzykiv [Text]: Monograph / I. M. Saraieva. - Odesa: Feniks, 2008. - 147 p.

22. A Risk Management Standard [Electronic resource] // FERMA. Federation of European Risk Management Associations. - Available at: \www/URL: http://www.ferma.eu/app/uploads/2011/11/ a-risk-management-standard-russian-version.pdf

\section{ИССЛЕДОВАНИЕ ТЕНДЕНЦИЙ УЛРАВЛЕНИЯ РИСКАМИ В УКРАИНЕ}

Рассмотрено современное состояние управления рисками в Украине. Выделены основные факторы хозяйственного риска для украинских предприятий. Выявлены потребности украинской системы управления рисками, а также специфические особенности отечественного риск-менеджмента, обоснована необходимость его дальнейшего исследования и развития. Предложено процедуру выбора мероприятий по управлению рисками на промышленных предприятиях.

ключевые слова: управление рисками, факторы риска, методы риск-менеджмента.

Posokhov Igor, Doctor of Economics, Professor, Acting Head of Department of the Organization of Production and Management Personnel, National Technical University «Kharkiv Polytechnic Institute»,Ukraine, e-mail: posokhov7@gmail.com, ORCID: http:// orcid.org/0000-0001-9668-642X

Khodyrieva Oksana, LLC «Experimental Plant «State Scientific Center of Medicines»», Kharkiv, Ukraine, e-mail: oksana.hodireva@gmail.com, ORCID: http://orcid.org/0000-0002-9761-4943

\section{Kovshun $\mathbf{N}$., Yakymchuk A., Kushnir $\mathbf{N}$. \\ RESEARCH OF THE ROLE OF THE WATER MANAGEMENT COMPLEX IN THE FORMATION OF FINANCIAL FLOWS}

Показано роль та особливості водогосподарської ренти у генераиії екологічних фінансових потоків. Визначено потенціал таких платежів на основі порівняння фактичних показників з розрахунковими. Розрахунки проведено в розрізі галузей економіки та регіонів. Поєднання цих підходів дало змогу побачити наявний рівень рентних надходжень та визначити перспективи ïх коригування.

Ключові слова: водогосподарський комплекс, водна рента, фіскальна віддача, інвестиційна віддача.

\section{Introduction}

An important economic mechanism of the financial market of the state is payments for the use of water re- sources. It is through the generation of these payments that significant financial flows are formed that contribute to the development of the water management complex (WMC) and its provision with the necessary means. The experience 